\title{
Vitamin D Levels in Patients With Ankylosing Spondylitis and Its Relationship With Disease Activity
}

\author{
Nilgün ÜSTÜN, Ayşe TURHANOĞLU \\ Department of Physical Medicine and Rehabilitation, Medical Faculty of Mustafa Kemal University, Hatay, Turkey
}

Ankylosing spondylitis (AS) is a chronic inflammatory disease affecting sacroiliac joints and axial skeleton. ${ }^{1}$ Although the etiology and pathogenesis of AS are not yet fully understood, it seems to be entirely immune system-mediated. Therefore, factors affecting the immune system may have effects on the disease course. One of these factors affecting the immune system is vitamin $\mathrm{D} .^{2}$

The relationship between serum vitamin $\mathrm{D}$ levels and disease activity scores in patients with AS has been studied in a number of studies ${ }^{3-5}$ with varying results. Based on this controversy, we aimed to elucidate the relationship between serum vitamin D levels and disease activity scores in AS patients as well as to compare vitamin D levels of AS patients with healthy individuals.

We designed a cross-sectional study including 75 consecutive patients with AS, and 35 ageand sex-matched healthy controls. The study was performed in winter to avoid seasonal variations in vitamin D levels. Disease activity was evaluated by Bath Ankylosing Spondylitis Disease Activity Index (BASDAI). Serum 25-hydroxyvitamin D (25-OH-D) levels were measured using chemiluminescence by ARCHITECT i2000.

There was no significant difference in vitamin $\mathrm{D}$ levels between the patients and controls $(14.20 \pm 7.36$ $\mathrm{ng} / \mathrm{mL}$ vs. $14.57 \pm 6.13 \mathrm{ng} / \mathrm{mL}$, respectively; $p=0.623)$. Vitamin $D$ levels in the control group were also very low, which may be explained by the common vitamin $\mathrm{D}$ deficiency problem in Turkey depending on many factors. ${ }^{6}$ The high incidence of vitamin D deficiency in our patients and controls may also be due to the winter season.

There was no significant difference between the patients with or without active disease in terms of serum vitamin $\mathrm{D}$ level $(13.74 \pm 8.83 \mathrm{ng} / \mathrm{mL}$ vs. $14.44 \pm 6.59 \mathrm{ng} / \mathrm{mL}$, respectively; $\mathrm{p}=0.514$ ). There was no significant correlation between vitamin D levels and BASDAI scores $(r=-0.035$, $\mathrm{p}=0.765$ ). Although the relationship between serum vitamin $\mathrm{D}$ levels and disease activity in AS has been studied in a number of studies, ${ }^{3-5}$ only one study showed a relationship between 25-OH-D levels and disease activity. ${ }^{4}$ Lange et al. ${ }^{5}$ reported a correlation between disease activity in AS and 1,25-OH-D metabolites levels; however, not with 25-OH-D. We used 25-OH-D which is the major circulating form of vitamin $\mathrm{D}$.

Our study results demonstrated no significant difference in serum vitamin $\mathrm{D}$ levels between AS patients and healthy controls. Besides, no significant correlation was shown between vitamin $\mathrm{D}$ levels and disease activity index. However, further prospective studies investigating the possible effects of vitamin D supplements or diet/sun exposure on disease activity parameters in patients with AS are needed. 


\section{Declaration of conflicting interests}

The authors declared no conflicts of interest with respect to the authorship and/or publication of this article.

\section{Funding}

The authors received no financial support for the research and/or authorship of this article.

\section{REFERENCES}

1. Braun J, Sieper J. Ankylosing spondylitis. Lancet 2007;369:1379-90.

2. Arnson Y, Amital H, Shoenfeld Y. Vitamin D and autoimmunity: new aetiological and therapeutic considerations. Ann Rheum Dis 2007;66:1137-42.
3. Erten S, Kucuksahin O, Sahin A, Altunoglu A, Akyol M, Koca C. Decreased plasma vitamin D levels in patients with undifferentiated spondyloarthritis and ankylosing spondylitis. Intern Med 2013;52:339-44.

4. Durmus B, Altay Z, Baysal O, Ersoy Y. Does vitamin $\mathrm{D}$ affect disease severity in patients with ankylosing spondylitis? Chin Med J (Engl) 2012;125:2511-5.

5. Lange U, Teichmann J, Strunk J, Müller-Ladner $\mathrm{U}$, Schmidt KL. Association of 1.25 vitamin D3 deficiency, disease activity and low bone mass in ankylosing spondylitis. Osteoporos Int 2005;16:19992004.

6. Satman İ, Çolak Özbey N, Boztepe H, Kalaca S, Omer B, Tanakol R, et al. Prevalence and of vitamin D deficiency and associated factors in Turkey. On behalf of the TURDEP-II Study Group. Endoc Rev 2012;33 [Meeting Abstracts] MON 349. 